\title{
The Camp Pearl Wheat Site 41KR23 A Program for Data Recovery
}

Follow this and additional works at: https://scholarworks.sfasu.edu/ita

Part of the American Material Culture Commons, Archaeological Anthropology Commons, Environmental Studies Commons, Other American Studies Commons, Other Arts and Humanities Commons, Other History of Art, Architecture, and Archaeology Commons, and the United States History Commons

Tell us how this article helped you.

This Article is brought to you for free and open access by the Center for Regional Heritage Research at SFA ScholarWorks. It has been accepted for inclusion in Index of Texas Archaeology: Open Access Gray Literature from the Lone Star State by an authorized editor of SFA ScholarWorks. For more information, please contact cdsscholarworks@sfasu.edu. 


\section{The Camp Pearl Wheat Site 41KR23 A Program for Data Recovery}

\section{Licensing Statement}

This is a work produced for the Texas Department of Transportation (TxDOT) by the report producer. TxDOT and the report producer jointly own all rights, title, and interest in and to all intellectual property developed under TXDOT's contract with the report producer. The report may be cited and brief passages from this publication may be reproduced without permission provided that credit is given to both TxDOT and the report producer. Permission to reprint an entire chapter, section, figures or tables must be obtained in advance from either the Supervisor of the Archeological Studies Branch, Environmental Affairs Division, Texas Department of Transportation, 125 East 11th Street, Austin, Texas, 78701 or from the report producer. 
THE CAMP PEARI WHEAT SITE

41 KR 23

A PROGRAM FOR DATA RECOVERY

\section{TEXAS}

State Department of Highways and Public Transportation

Highway Design Division 


\section{TABLE OF CONTENTS}

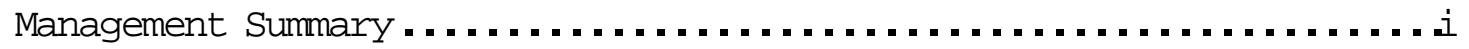

List of Figures.................................. ii

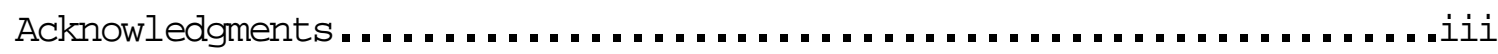

INTRODUCTION . . . . . . . . . . . . . . . . . . . . . . . . . . . . . . 1

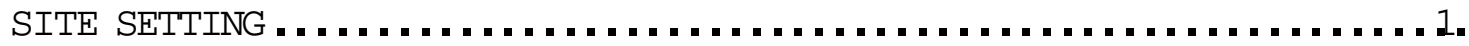

ARCHAEOLOGICAL BACKGROUND. . . . . . . . . . . . . . . . . . . . . . 5

The Early Archaic of Central Texas.......................5

Early Archaic Site Investigations..................... 7

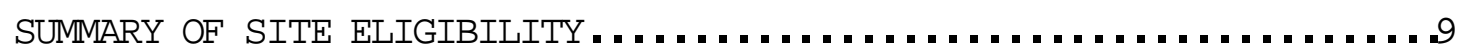

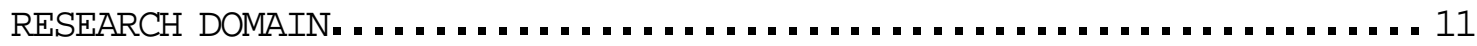

41KR243 As A Manifestation of The Central

Texas Early Archaic.................................11

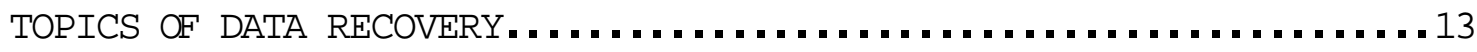

RESEARCH OBJECTIVES AND METHODOLOGY......................... 17

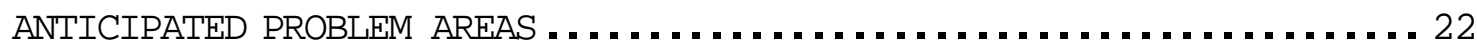

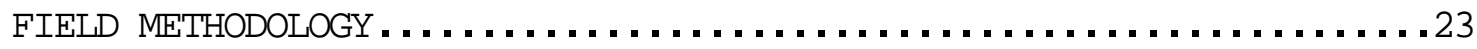

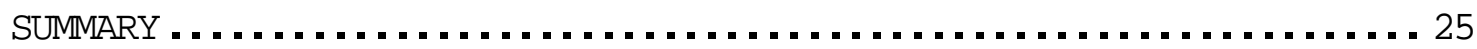

APPENDIX 1: The Martindale Projectile Point Type

As A Horizon Marker of the Regional Early Archaic.............. 26

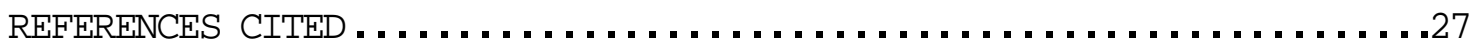




\section{MANAG E M NT SUMMARY}

This report presents a program for data recovery at the Camp Pearl Wheat Site, 41KR243, a prehistoric occupation in Kerr County, central Texas. First identified by the State Department of Highways and Public Transportation in early 1988, the site was later investigated by limited testing in June of that year. Interpretations of recovered materials and cultural deposits indicated that the locale may have a significant potential to yield data on a single component of the regional Early Archaic Period. This time span is poorly understood within Texas and it is believed that a further investigation of $41 \mathrm{KR} 243$ will offer archaeological information important to that period. 


\section{I S T O F FIGURES}

Figure No.

1 Location of 41KR243, Kerr County, T ex a s................

$2 \quad$ SiteMap of $41 K R 243$ Showing Units Excavated

During Testing ................................. 


\section{ACKNOWIEDGMENTS}

The compilation of this report involved the efforts of a number of individuals from the Environmental Section, Highway Design Division, State Department of Highways and Public Transportation, Austin. A. Joachim McGraw reviewed and compiled this version of the data recovery program; Dr. Frank A. Weir also reviewed the draft and archaeologists Alan Wormser and Wayne Young contributed substantial portions to the text. Dr. Eugene Smith and Ann Irwin coordinated the production effort. All work was done under the supervision of Kenneth Bohuslav, P.E., Engineer of Environmental Studies. Versions of this work were reviewed by the staff of the State Historic Preservation Office, Texas Historical Commission, Austin. Alan Stanfill of the Advisory Council for Historic Preservation, Denver, Colorado, also offered comments that contributed to qualitative efforts of the data recovery program. 


\section{INTRODUCTION}

Site 41KR243, the Camp Pearl Wheat Site, is located along FM 783 and the south bank of Town Creek in Kerr County, central Texas (Fig. 1). The site was identified and recommended for testing by the State Department of Highways and Public Transportation (SDHPT) in response to plans for realigning a hazardous curve on FM 783. Test excavations were performed in June 1988 and consisted of three 2-meter square hand-excavated units within the proposed 120 foot wide right-of-way. Although testing was limited because a portion of the site is used as a summer youth camp, Camp Pearl Wheat, sufficient data was recovered to suggest that the site contains intact features at depths of 40 to $50 \mathrm{~cm}$. A hearth eroding from an existing roadcut was recorded and an another intact burned rock cluster was found at a depth of $50 \mathrm{~cm}$ in Test Unit 1 . The single diagnostic artifact from the testing phase, a Martindale dart point, closely resembled a dart point of the same style that was surface collected earlier when the site was originally identified.

Testing indicated that site stratigraphy consisted of approximately $30 \mathrm{~cm}$ of dark gray silty clay intermixed with infrequent occurrences of subrounded limestone pebbles, overlying a dark brown silty loam. The 2-meter square test units were excavated in $10-\mathrm{cm}$ levels that indicated the upper soil zone contained a very small amount of lithic debris. No burned rocks, bone, mussel shell, or stone tools were found. The absolute frequency of lithic debris per unit from this upper zone ranged from 1 to 25 and suggested an ephemeral temporary cultural presence. The lower dark brown silty clay level, however, the level which contained the exposed hearth and the Martindale dart point, had a higher frequency of lithic debris per level than the upper zone. Burned or fire-fractured rock was noted in all units within the deeper zone but no bone, mussel shell, or charcoal was observed.

Although testing indicated that the prehistoric occupation was most intensive in the western half of the proposed right-of-way, the site did extend eastward across the right-of-way. Approximately 1000 square meters of relatively undisturbed site surface area lies within the project limits. Based on limited testing and intensive surface survey, an estimated 60\% of the site is contained in the roadway right-of-way. Test Unit 3, the southernmost unit dug, was located either at or very near the southeastern margin of the site (Fig. 2). The original site dimensions, prior to disturbance by the first construction of FM 783, was estimated at approximately 70 × 40 meters.

\section{SITE SETTING}

The Camp Pearl Wheat site is situated within the eroding limestone hills of central Texas adjacent to Town Creek, a tributary of the upper Guadalupe River drainage system. Landforms are often composed of steep, juniper or oakcovered mesas or buttes of high relief within the natural setting of the 
This Page Redacted Per THC Policy 
Edwards Plateau. 41KR243 is located near the cuesta, or stream divide, that separates the Guadalupe River drainage from the Pedernales River system; the latter is less than 10 miles to the northeast.

Site 41KR243 is located along an upper Pleistocene terrace at the Town Creek/FM 783 crossing about 2.5 miles north of Kerrville, Texas. The site is situated along the western end of a long and flat terrace and is limited on the west by FM 783 and on the north by Town Creek. The terrace and the site area have been a part of Camp Pearl Wheat for at least 25 years and some disturbances to the original area are presumed to have occurred.

Except for a few large native juniper trees, almost all of the large trees have been removed from the terrace along the present right-of-way and along the creek edge. There are native live oak trees just south of the right-ofway which shade the camp's volleyball courts. A private caliche roadway crosses the site within the proposed right-of-way and divides the site into east and west halves. The westernmost 4 meters of the proposed right-of-way includes current highway backslopes and the site has been effectively removed from this area. In addition, the northernmost 4-8 meters appear to have been severely eroded. This area has large gravels and pebbles on the surface which are similar to those located at a depth of $45 \mathrm{~cm}$ in Test Unit 2 . A small cement-lined drainage ditch that extends from the roadway toward the creek has displaced a small portion of the site's cultural deposits.

The observed disturbances are considered to be relatively minor and most have had no adverse impact on the identified Early Archaic cultural deposits. A small portion of the site has been eroded by the gully and a larger area has been removed by highway construction and maintenance activities over the years. It appears that the 120 feet wide right-of-way contains roughly 1000 square meters of surface area that may overlie subsurface, intact, cultural deposits. 


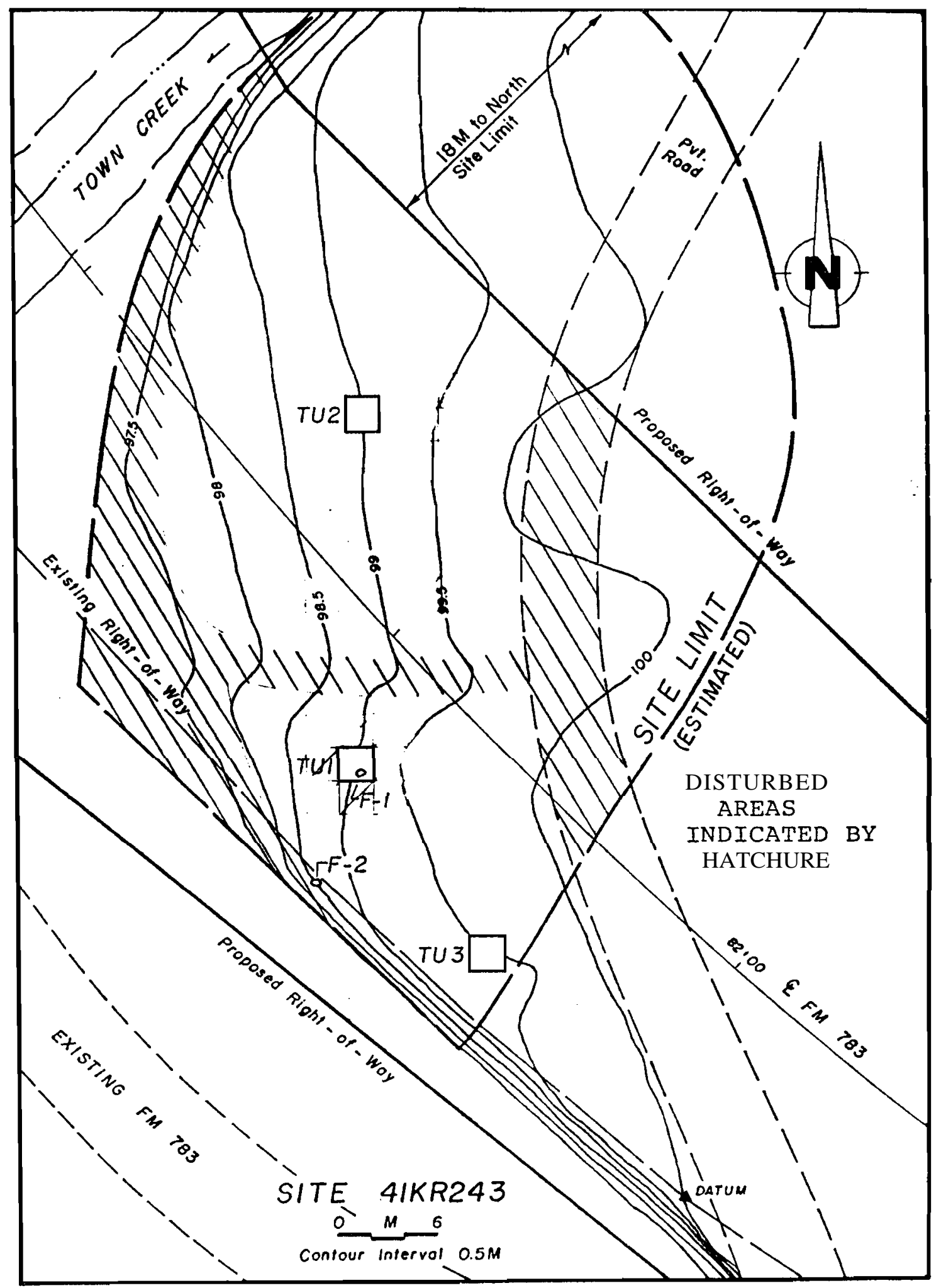

Figure 2. Site Map of $41 K R 243$ showing units excavated during testing operations. 
$41 \mathrm{KR} 243$

Data Recovery Program
ARCHAEOLOGICAL BACKGROUND

Page 5

\section{ARCHAFOIOGICAI BACKGROUND}

The Pearl Wheat Site is located within the central Texas geographical area, a region that is characterized by distinctive patterns of both flora and fauna that are associated with the Edwards Plateau. Only broadly understood in a cultural-geographical context, the archaeological remains of the central Texas area are, more often than not, dominated by a variety of chronologically or otherwise diagnostic lithic tool forms, occasional examples of modified bone, infrequent occurrences of ceramics, and the scattered clusters of firefractured rock at occupation sites. The reflections of hunter-gatherer subsistence patterns predominate the archaeological record from the PaleoIndian Period of ca. 12,000 B.P. to those of the more recent Indians encountered during intrusions of Spanish Colonial expeditions into the region in the late 17 th century A.D.

The longest span of hunter-gatherer lifeways associated with the pursuit and collection of modern (Holocene) fauna and flora has been identified regionally as the Archaic Period. Divided into early, middle, late, and possibly, transitional, stages, the time span of the Archaic ranges from the end of the Paleo-Indian Period to the first millenium A.D., ca. 6000 B.C. - A.D. 800900. Distinctive changes and innovations in technology and tool forms after this time separate the Archaic Period from the more recent Late Prehistoric and Proto-Historic Periods.

Excluding the earlier cultures of the Paleo-Indian Period, the peoples and cultures of the regional Early Archaic are the most poorly understood within the archaeological record of Texas. 41KR243 near Town Creek represents one of the few Archaic sites to be reported with a discrete, intact, early component. While a systematic review of the regional prehistory is beyond the scope of this data recovery plan, a short discussion of the Early Archaic time frame, as it is understood to date, is presented below. Such a review will present $41 \mathrm{KR} 243$ within the context of a regional geographic and possibly culturalgeographical perspective.

\section{The Early Archaic of Central Texas}

The Early Archaic in central Texas is recognized primarily by a variety of distinctive lithic projectile points and tool forms such as distally beveled tools, or gouges. Although very little specific information is known of activities or cultural traits of peoples from this time, a number sites containing Early Archaic artifacts have been reported in the last 50 years. Several factors, however, have limited the amount of information brought to light from such work:

1. While diagnostic artifacts associated with this period have been found somewhat infrequently in the region, more often than not, they were identified in mixed contexts at multi-component site locales. Consequently and 
$41 \mathrm{KR} 243$

Data Recovery Program

ARCHAEOLOGICAL BACKGROUND

Page 6

unfortunately, such materials were often misidentified or remained as unidentified within the typologies of the reports' artifact descriptions.

2. Several intact components have been identified previously but were only minimally tested because of time, personnel, or funding limitations.

3. A significant amount of archaeological research occurred more than a decade past and research methodologies and strategies, valid for the time, could now be considered too limited. The resultant information from such work, although still valuable as primary research data, does not offer the detail of information necessary for inter-site distribution studies or current technological analyses.

The Early Archaic of central Texas, as part of an overall chronological view of the Archaic Period, has been subdivided into several phases delimited by temporal intervals and perceived cultural traits. Researchers such as Weir (1976) and Prewitt (1981) relied heavily on a number of dart point types to develop phase constructs since there was little other temporally sensitive data available. When Weir proposed the San Geronimo Phase in 1976, he suggested a wide cultural range for the phase that offered future researchers opportunities for a more refined breakdown. Prewitt took on this task in 1981.

The Early Archaic has not been well dated by radiocarbon assays because of poor associations with chronologically diagnostic tools and the paucity of acceptable carbon samples. Weir (ibid.) postulated his San Geronimo time span as ranging from approximately 8000 - 4500 B.P. Prewitt (1981) suggested dates of 5,000 - 6000 B.P. for his Jarrell Phase, 6000 - 7,000 B.P. for his San Geronimo Phase and 7,000 - 8,500 B.P. for his Circleville Phase. Unfortunately, Prewitt lacked radiocarbon assays to substantiate these dates. Most recently, during the 1984 excavations at 41WM235 in Williamson County, a date of ca. 7470 B.P. was obtained from a zone containing both Gower and Angostura tool types.

Weir's San Geronimo's Phase equated with the regional Early Archaic and included dart point types as horizon markers that were commonly found in Early Archaic sites in central Texas. The lanceolate Angostura form, usually considered a Late Paleo-Indian projectile point form, has been found in Early Archaic contexts and was included in Weir's San Geronimo Phase. Prewitt (ibid.) however, placed the Angostura type and associated cultural traits in his Circleville Phase that also contained Golondrina, Merserve, and Scottsbluff types as horizon markers. Prewitt's San Geronimo Phase includes Gower, Hoxie, and Wells dart points and Clear Fork gouges or distally beveled tools. His later Jarrell Phase included representative projectile points such as Andice, Bell, Martindale, and Uvalde dart points, Clear Fork tools, and grinding stones. All of these chronologically diagnostic artifacts were previously in Weir's San Geronimo Phase. 
$41 \mathrm{KR} 243$

Data Recovery Program
ARCHAEOLOGICAL BACKGROUND

Page 7

Early Archaic Site Investigations

Early Archaic sites in central Texas that have offered substantial contributions to the existing archaeological data base include the Youngsport Site Shafer 1963), the Landslide Site (Sorrow, et. al. 1967), 41WM56, 41WM57, and 41WM267 (Hays 1982), the La Jita Site (Hester 1971), Jetta Court (Wesolowsky, et. al. 1976), and 41BX228 (Black and McGraw 1985). Two other site reports currently in preparation by the Texas SDHPT, 41BC65 and 41WM235, should also measurably contribute to a better understanding of this time period.

The Youngsport Site (Shafer 1963) was one of the first Texas sites in which a distinct Early Archaic component was recognized and became the type site for the Gower projectile point. The site was tested using volunteer labor who excavated 9 test units. Vertical stratigraphy indicated a separation of the Gower from recognized Middle Archaic projectile points such as Nolan, Travis, and Bulverde. Stratum 8 at the site was associated with the Early Archaic component and yielded 15 dart points, several other lithic tools, and a Clear Fork tool. No features, bone, or ground stone were noted or recovered. Additional data was somewhat limited due to excavation techniques and thencurrent methodologies.

The Landslide Site in Stillhouse Hollow Reservoir (Sorrow et al. 1967), became the type site for Bell, another diagnostic projectile point of the Early Archaic. Similar to the Youngsport site, the Landslide Site was located on a terrace having intact cultural deposits. Underlying Middle Archaic deposits, the site's Stratum V contained Gower, Martindale, and other untyped points. Burins, large unifaces, grinding implements, and other lithic tools were also recovered. Hearths were usually large and composed of flat limestone rocks paving a circular area. The burned rock clusters were either circular and flat or slightly basin shaped. Mussel shell was abundant throughout the site. Site investigations seemed to indicate that Gower and Martindale projectile points were earlier than the Bell type and that there were possible cultural differences within the Early Archaic of central Texas. It is also possible that 6 -inch excavation levels may have affected site interpretations; McGraw and Hindes (1987: 122) noted an apparent association of Martindale and Bell projectile points and Guadalupe distally beveled tools within a discrete burned rock feature at 41BX274, an Early Archaic campsite recently identified in Bexar County.

A major site report resulting in the identification of significant Early Archaic deposits occurred with Hester's (1971) publication of 41UV21, the La Jita Site, Uvalde County. Hester identified several variants of what he tentatively described as Early Corner Notched points as being associated with the lower cultural levels of the site. Most of the twenty-two specimens of this group resembled the Martindale type although two other varieties were noted. Additionally, a tentative new type, La Jita, was described but the chronological context, except as an Early Archaic point type, was not clear. 
The Jetta Court Site (Wesolowsky et al. 1976) was conducted as a salvage excavation by volunteers. Only three 2-meter squares were opened because of the extensive vertical deposits and this limited horizontal site interpretations. The site contained two burned rock midden zones separated vertically by a culturally sterile zone. The lower midden contained Gower, Bell, and other untyped dart points while the upper midden deposit contained diagnostic artifacts associated with the Middle and Late Archaic and more recent Late Prehistoric Periods. Other than a zone containing burned rock, no other features were noted within the lower midden. It should be noted here that Wesolowsky's lower midden zone, ca. $40 \mathrm{~cm}$ thick, should be viewed as a concentration of burned limestone rock, snail shells and cultural debris. This may or may not (and is thought not to be) siniliar to Middle Archaic middens composed almost totally of large accumulations of fire-fractured rock. Wesolowsky's description of the lower cultural deposit appears to similar to the Early Archaic deposit identified as Area M in Black and McGraw's (1985) excavations of 41BX228, the Panther Springs Creek Site (see following discussion). Black and McGraw noted a deposit similar to that of Jetta Court ca. $50 \mathrm{~cm}$ thick underlying and essentially sealed by later Archaic midden deposits.

Hays (1982) has presented more recent research from North Pork and Granger Reservoirs in Williamson County. Site 41WM56 contained components that ranged from the Early Archaic through the Late Prehistoric Periods. Recognizable vertical separation was noted between various occupation levels. Excavations at 41WM57 (ibid.) identified a burned rock midden and material deposits that included a long span of Archaic occupations. Early Archaic deposits were detected in only two units and interpretive value was limited. Hays (ibid.) also recovered data on the Early Archaic from 41WM267 although the tool density for this site was very low and no ground stone was recovered. Features consisted of clusters of burned rock, basin-shaped hearths, and concentrations of ash and heat-altered soils.

The Panther Springs Creek Site, 41BX228, in south-central Texas and along the margins of the Edwards Plateau, also revealed significant Early Archaic deposits when excavated in 1985 by Black and McGraw. Approximately 60 miles southeast of 41KR243, the Panther Springs Creek Site was identified as a multi-component prehistoric terrace occupation locale. An isolated Early Archaic deposit was uncovered, sealed below a Middle Archaic burned rock midden. Associated lithic tools and diagnostic artifacts included Bell, Martindale, Early Triangular bifaces, other identified dart points, Clear Fork and Guadalupe distally beveled tools, grinding stones, and debris from lithic reduction sequences. Clusters of fire-fractured limestone rock often associated with adjacent pits were also noted.

Most recently, future data from two sites with as yet, unpublished site reports, 41BC65 and 41WM235, should offer substantive contributions to an understanding of the regional Early Archaic. The Sleeper Site, 41BC65 in Blanco County (Johnson, in press), contained a buried occupation with several hearths and burned rock scatters. Located on a shallow terrace, the site deposits indicated two Early Archaic components. A collection of projectile 
$41 \mathrm{KR} 243$

Data Recovery Program
ARCHAEOLOGICAL BACKGROUND

Page 9

points included Gower, Martindale, and Uvalde. Unlike other sites previously discussed, 41BC65 also contained an unusually large number of ground stone tools.

The Wilson-Leonard Site, 41WM235, was excavated by the SDHPT in 1983-1984 and contained an extensive deposit of Early Archaic remains. Features consisted of a number of burned rock clusters. The size ranges of these clusters appeared to be temporally discrete. While the data has only been partially analyzed, the eventual site report, like that of 41BC65, should offer new insights into this time period.

In summary, although a number of sites within the central Texas area have been previously identified as containing significant Early Archaic deposits, it has only been relatively recently that a refined focus of investigations has both defined more clearly some aspects of the period and generated more questions that must be addressed by future researchers. The current subdivisions, or phases, of the regional Early Archaic are still only broadly and perhaps inadequately defined. Integrally linked to the limitations of relying heavily on diagnostic projectile points for temporal constructs is the necessity for a more refined definition of an Early Archaic cultural-geographical region. Given the wide spatial distribution of many of the diagnostic tool types associated with the Early Archaic, it may be overly simplistic to infer that the geographical region of central Texas was once a former culturalgeographical area.

These comments have been addressed in some detail by Black and McGraw (1985: 318-326) and more recently by Johnson (1987: 1-26) .

The chronological aspects of the Early Archaic have been recognized and reviewed by such researchers as Weir (1976) and Prewitt (1981) in recent years. Although imperfect in constructs due to the limitations of substantive data, such perspectives are still a marked refinement from the earlier accomplishments of such researchers as J. Charles Kelley (1959), Jelks (1962), and Suhm (1960). The future, better, understanding of the cultural complexes associated with the central Texas Early Archaic may result from a perspective that Willey and Phillips (1958: 27) once recommended; that a regional sequence should be constructed from local sequences and local sequences should be built from comparisions of individual sites. The significance of local sequences cannot be overstated and researchers of over a decade have refocused on this point (e.g., Johnson et. al. 1962 and Black and McGraw 1985:318-326).

\section{SUMMARY OF SITE EIIGIBIIITY}

The Camp Pearl Wheat Site, 41KR243, is considered eligible for inclusion to the National Register of Historic Places based on selection criterion D:

...Properties may be eligible for the National Register if they have yielded, or may be likely to yield, information important in history or prehistory.

Significant data potential is directly related to archaeological information that may contribute to a better understanding of cultural traits, associated 
$41 \mathrm{KR} 243$

SUMMARY OF SITE ELIGIBILITY

Data Recovery Program

Page 10

materials, and the chronology of the regional Early Archaic Period in central Texas. Broad research topics important to the study of this period include cultural chronology, cultural adaptions and subsistence patterns, and possible definitions of the resource base.

The significance of 41KR243 lies in the opportunity to study an isolated component from a recognized phase of the Early Archaic Period. Most identified sites in central Texas presently consist of mixed assemblages and components. It is thus rare to find a site with a discrete occupation from the Early Archaic. It is expected that undisturbed features and activity areas may be uncovered that will more clearly reflect the lifeways and cultural traits of prehistoric peoples who once manufactured and utilized such highly distinctive projectile point forms as the Martindale type. Such potential information would offer a significant contribution to the understanding of the local and regional archaeological record. 


\title{
RESEARCH DOMAIN
}

\author{
41KR243 As A Manifestation of The Central Texas Early Archaic
}

Site 41KR243 may have once been a multicomponent site. However, the portion of the site impacted by the bridge replacement project and which was tested by the SDHPT revealed only a single component from the Early Archaic as recognized in central Texas. Because the proposed investigation will focus on a discrete occupation from a particular period, emphasis in this document will concentrate on that part of the prehistory of the region. A discussion of site potential for significant data recovery is presented below. 41KR243 will be viewed from the perspective of an individual site locale and its relationship to recognized regional phases as described by Weir (1976), Prewitt (1981), and as commented on by Johnson(1987: 1-27) (see also ARCHAEOLOGICAL BACKGROUND section for an introduction to a discussion of regional phases).

As noted, the chronological sequences of the central Texas Archaic are presently based primarily on projectile point typologies and associated radiocarbon dates. Currently two versions of the chronology are in use: Weir (1976) has suggested a sequence which is more generalized and contains five phases or time periods. On the other hand Prewitt (1981) took Weir's time periods and split them into more categories. Johnson(1987) criticized both schemes on methodological and theoretical grounds. The definition of the San Geronimo Phase represented the total of the Early Archaic Period in Weir's scheme while Prewitt separated this same time period into the Circleville, San Geronimo, Jarrell, and Oakalla Phases. None of these are true phases in the traditional definition of Willey and Phillips(1958) but are rather only temporal refinements beyond the constructs as discussed by Weir. Based on the recovery of chronologically diagnostic Martindale points recovered from the site, Prewitt's Jarrell phase best represents the occupation found at the site. It should be noted however, that Prewitt's definition of this phase appears to be much broader that what apparently is represented at 41KR243. Diagnostic artifacts from the Jarrell time period include Andice, Bell, Martindale, and Uvalde projectile points, Clear Fork gouges, miscellaneous bifaces, hammerstones, and grinding stones (Prewitt 1981: 78). Other possible attributes identified by Prewitt (ibid.) include:

Features: large, flat hearths

Subsistence: hunting and gathering with a probable tendency for an on gathering; bison present and used as a food source although hunting probably not dominant; freshwater mussels collected for food.

External Relations: This phase appears to be relatively localized to the Central Texas region except that Martindale dart points (and slight variants of the type) also occur in the Lower Pecos Region. Andice and Bell types possibly related to the same tradition represented by the morphologically similar Calf Creek type in northeastern Oklahoma, 
$41 \mathrm{KR} 243$

RESEARCH DOMAIN

Data Recovery Program

Page 12

northwestern Arkansas, and southwestern Missouri (Perino 1968: 14-15). Estimated Age: ca. 6000 B.P. to 5000 B.P. (ca. 4050 to 3050 B.C.) Discussion: Some holdovers exist from the Paleo-Indian lithic tradition, with frequent edge grinding on Martindale and Uvalde points and flaking reminiscent of that tradition on Andice points. Subsistence is thoroughly Archaic and probably tends toward an emphasis on gathering.

The material culture of the Jarrell phase, especially lithic artifacts but excluding diagnostic projectile points, is poorly understood. A significant characteristic of the Texas Early Archaic, both in central Texas and adjacent geographical regions, appears to be the regionalization of specific tool forms, a diversity of types (versus the predominance of a single form), and the marked variants of recognized projectile point types. This is typified in the distribution of the distinctive Early Archaic Guadalupe tool form which some researchers (e.g., Black and McGraw 1985: 142-156) reasonably associated with Gower, Martindale, and Bell projectile points. The identified distribution of Guadalupe tools appears restricted to the the southern Texas coastal plain between the San Antonio/Guadalupend Nueces Rivers drainage systems. The northern limits of this distribution appear to be along the margins of the Edwards Plateau, the Balcones Escarpment, and thus would be approximately 40 miles south of 41KR243. The significance of this and other distinctive tool types -their presence or absence and function- within an Early Archaic lithic assemblage cannot be overlooked as the co-occurring projectile points have a much wider inter-regional distribution.

Peoples associated with the Jarrell Phase as decribed by Prewitt (1981) or the equivalent recognized span of the Early Archaic are thought to have consisted of small bands of semi-nomadic hunter-gatherers who were highly attuned to the exploitation of seasonal resources. A major distinction within the feature remains of the archaeological record of this time period is the lack of large accumulations of burned limestone rock, or middens, that characterize many later Middle Archaic occupation sites throughout central Texas. The Early Archaic is also distinguished from the preceding Paleo-Indian Period by the associated modern (Holocene) environmental conditions thought to have taken place after ca. 6500 B.P.

Resource exploitation and patterns, both on a site-specific and more general level, of the associated cultural groups are poorly understood because of the lack of preservation of perishable remains and the paucity of all but stone materials. If ethnographic interpretations of early historic hunter-gatherer groups within or adjacent to the region can shed any light on prehistoric patterns, Campbell (1981) suggested a biolobate seasonal exploitation strategy across a wide-ranging area. McGraw and Hindes (1987: 366-367) also commented on the potential for more generalized prehistoric transphysiographic subsistence patterns not inclusive of biolobate migrational rounds. 
A significant feature of $41 \mathrm{KR} 243$ is its location near a major tributary of the upper Guadalupe River and the site's proximity to the adjacent Pedernales River; the latter a major stream of the Colorado River drainage. The site's location within this natural setting may infer a prehistoric potential for inter-drainage, if not transphysiographic resource exploitation patterns. The distinctive physiography and natural resources of the upper Guadalupe drainage also sharply contrasts with the environmental character of the same river system less than 50 miles southward toward the inland prairies of the Gulf Coastal Plain.

In summary, researchers cannot currently distinguish such differences as ethnicity, origins, or cultural relationships between different population groups represented within the central Texas Early Archaic. Weir (1976), for example, has suggested that during this time frame a diverse population was in place with considerable inter-group contact and flucuation. It is likely that Prewitt's (1981) Jarrell Phase identifies a collection of hunter-gatherer groups with similar, generalized adaptations. It would be reasonable to postulate inter-regional cultural diversity but current information cannot yet make such identifications possible.

\section{TOPICS OF DATA RECOVERY}

An understanding of the Early Archaic occupation at 41KR243 in scope is generally similiar to an understanding of other aspects of later Archaic lifeways. Research goals are necessarily directed toward the recognition of cultural change and continuity, temporal and spatial dimensions, and the identification of both material and intangible cultural characteristics that distinguish this regional episode of the prehistoric past.

The topics of data recovery are both site-specific and are also much broader, on the level of inter-site comparisions that view the Camp Pearl Wheat Site as representative of discrete cultural phenomenon over a far-ranging area. As such, the primary goals of data recovery, utilizing methodologies that are as quantifiable as possible, are to: 1) accurately collect or identify material evidences of former activities; 2) assess the character and formation of natural soil processes and their influence on cultural deposits; 3) offer site-specific data within the final report as a basis for interpretation of site function and occupation; 4) offer a comparison of inter-site similarities and differences to other sites in a similar spatial and temporal context; 5) discuss contemporaneous sites in non-local and non-similar settings and; 6) from the perspective of specific site information and inter-site comparisons, offer a refined view of the Early Archaic cultural complex associated with Martindale horizon markers, ca. 4000 - 3000 B.C. The spatial and temporal refinements are considered critical to any interpretations of site activities or other identified cultural characterisitics. 
$41 \mathrm{KR} 243$

Data Recovery Program

TOPICS OF DATA RECOVERY

Page 14

Primary research questions considered relevant to the investion of $41 \mathrm{KR} 243$ are listed below as 7 general or specific topic areas. Research objectives and methodologies based upon these topics are presented in the following sections. All research questions should be considered from both site-specific and intersite perspectives.

1. Site Function

A. What were the range of activities conducted at the site and how can they be recognized or postulated?

B. What types and what are the characteristics of site features?

C. Can features be related to other aspects of site activities such as food preparation, resource exploitation, technologies (such as lithic), or group (population) size?

D. Can intra-site activity patterns be identified?

\section{2. $\quad$ Site setting}

A. On the assumption that $41 \mathrm{KR} 243$ is a single component locale, what local physiographic or other environmental characteristics have contributed to or influenced site occupation?

B. What (if any) recognizable changes have occurred to limit the span of site occupancy?

C. How can the geomorphological and other characteristics of the natural setting be compared to other both local and non-local Early Archaic sites?

3. Determinations of Local Resources (Subsistence)

A. Can patterns of former resource exploitation be determined from recovered faunal and botanical remains?

B. Do such patterns or recovered data indicate changes in climate or other environmental conditions?

C. Do distributions of floral and faunal remains at $41 \mathrm{KR} 243$ and other Early Archaic sites represent or indicate seasonality of exploitation or of occupation periods, food processing, or other activities?

D. Can the intensity of site activities be used to infer local resource productivity?

E. What identified and postulated activities can be inferred from recognized types of food resources? Can types of processing be detected? 
F. Do recognized site features indicate an emphasis on specific types of processing or is a broader range of subsistence or food collection indicated?

G. Does 41KR243 represent a specialized site in relation to resource exploitation or can it be considered a multi-functional campsite or base camp?

H. Do specific tool types and their frequency indicate specialized processing activities; for example, does the presence and frequency, or absence of ground stone tools indicate particular site or intra-site functions?

I. Other Archaic sites in central and south-central Texas indicate a marked emphasis on white-tailed deer (Odocoileus [or Dama] Virginianus) as a faunal resource. Is this also the case at 41KR2 43 and do recovered material indicate selective butchering or hunting processes?

\section{Population Size and Social Organization}

A. Can population estimates be made of site-specific groups based on site features, intensity of activities, or other criteria?

B. Can activitiy-specific areas be delimited that infer male/female or sex-specific activity patterns?

C. Can such features as burned rock clusters and their spatial patterning be used to identify the ephemeral locations of once temporary occupation structures? Can such features as post molds be detected in these locales?

D. If encountered, will such features as caches, burial offerings, or internments indicate distinctive social, religious, or ceremonial traits?

\section{Technology and Typology}

A. What types of lithic tool kits are associated with Early Archaic sites and how are these similar or different from those identified at 41KR243?

B. Does a detailed analysis of formal and informal tool types and the characterisitics of lithic debris indicate specific traits of lithic production that may be used to delimit this time span of the Early Archaic?

C. Where are the identified lithic resource procurement areas in relation to 41KR243 and do such and other types of resource areas indicate a measurable radius or range of economic activities from the community locale?

\section{Temporal Context}

The temporal, or chronological, context of the data recovery program should be approached on three levels: 1) site-specific; 2) as a comparison 
$41 \mathrm{KR} 243$

TOPIC OF DATA RECOVERY

Data Recovery Program

Page 16

with other sites in a defineable local area and; 3) as site-specific data integrated into the background of a "regionally" described setting. Relevant questions that may be considered include:

A. What types of material evidence may be used to establish the relative and absolute ages of past human activities at 41KR243?

B. Can other methods in addition to such data as radiocarbon assays be used to infer a relative temporal context? Considered methods might include soils chemistry, geomorphology, or other soils analyses.

C. What are the morphological characterisitics of chronologically diagnostic artifacts and how do such compare with those from other sites of contemporaneous age?

D. What is the chronological context of the Martindale associated component within the recognized Jarrell Phase and can a temporal refinement be considered?

E. What other cultural elements as identified from 41KR243 might be used to more appropriately describe a Martindale-associated cultural complex? Additionally, how should this complex be more fully addressed before relating it to a regionally defined and recognized cultural phase.

F. What is the spatial distribution, extent, and variation within regional and inter-regional manifestations of the cultural complex?

G. Can site-specific data and inter-site comparisons shed light on the origins and adaptations of the Martindale-associated complex?

H. What evidence exists of interaction between other contemporaneous peoples of the regional Archaic and those of adjacent areas?

\section{Spatial Constructs}

A. How does $41 \mathrm{KR} 243$ differ from other sites within the upper Guadalupe River drainage system that have similar environmental characteristics?

B. Can site data be used to contribute to a recognition of interdrainage and intra-drainage heterogeniety of Early Archaic sites?

C. What types of synchronic relationships may be recognized between 41KR243 and other Early Archaic sites?

D. On a more local level, can a catchment area be defined for the Town Creek drainage and the vicinity of 41KR243? 
$41 \mathrm{KR} 243$

RESEARCH OBJECTIVES

Data Recovery Program

Page 17

\section{RESEARCH OBJECTIVES AND METHODOLOGY}

The data requirements of site investigations are discussed within the perspective of 7 research objectives. Specific approaches and methodologies toward data collection are reviewed, as well as variables that affect the validity of analytical interpretations.

41KR243, through the recovery of site-specific data, may offer two major contributions to the local and regional archaeological record: 1) the compilation of a systematically produced, quantifiable, information base that may be used comparatively by future researchers and; 2) site-specific generated data that will allow a refinement of the regional concept of cultural change and continuity within the Early Archaic Period and specifically as to how a Camp Pearl Wheat complex or Martindale-associated cultural complex relates to current perceptions of the regional phase concept.

Research objectives for site investigations will address the concerns and considerations of the previously identified topic areas of data recovery. A discussion of individual objectives and their proposed methodologies following the format of TOPICS OF DATA RECOVERY is presented below. It should be stated most strongly that all data recovery should be oriented toward the collection of quantifiable, comparative information. A shortcoming of previous works has been the lack of such detailed information. A significant contribution of $41 \mathrm{KR} 243$ to the regional archaeological record will be the development of such a comparative data base.

\section{1. $\quad$ Site Function}

Interpretations of site function will be a result of field work and laboratory analyses. Field efforts will be directed toward the identification of intrasite activity patterns, spatial distributions of material remains, and the detailed recordation of vertical and horizontal distributions of the same. Some aspects of site function are considered to be more easily recognizable than others, for example, concentrations of lithic debris may indicate former work stations but comparatively, little evidence may remain of such activities as food processing or ceremonial activities. Features are considered to be primary indicators of at least some functions and distinctions should be made between the morphologies of the ubiquitous burned rock cluster following the criteria described by White (1980: 66-73). Inter-site comparisons of Early Archaic site data are considered a necessity to recognize patterns of burned rock scatters or material distributions. Methodologies utilized will include the standard concepts of documentation and arbitrarily defined excavation levels unless a natural cultural stratigraphy may be identified and the episodes of a single cultural component recognized. Specific laboratory analysis strategies, particularly in the area of lithic studies, must be developed to recognize the range and variety of both tool types and debris. 
$41 \mathrm{KR} 243$

RESEARCH OBJECTIVES

Data Recovery Program

Page 18

\section{Site Setting}

The recognition of distinctive elements of the natural setting that characterize the site location is necessary to more accurately postulate not modern but prehistoric site conditions. Understanding the unique aspects of the site setting will contribute to an understanding of why prehistoric peoples selected 41KR243 as an occupation loci in preference over locations. A sitespecific and areal geomorphological review is recommended to identify such elements. Additionally, given that 41KR243 may be a single component site, site investigations should also discuss what natural conditions may have changed or altered to dissuade later peoples from reusing the area. Soils chemistry, wood species identification, and phytolith recovery may provide useful, quantifiable, and comparative data.

\section{Determinations of Local Resources}

41KR243 may yield both faunal and botanical remains that can be used to infer subsistence resources. Such efforts could be complemented by a systematic review of the existing natural flora and fauna within the surrounding area. Types and diversity of artifacts, features, and locations of natural resources could be further utilized to interpret resource exploitation. Resource productivity and intensity of site activities are two elements of previous site reports that have been addressed only in a cursory fashion. The development of quantifiable techniques to discuss these elements could substantially contribute a reproducable format for future comparisions. The development of such investigative techniques, although necessarily site-specific, may be patterned after or address Chisholm's (1968) model that the bulk of any community's economic activities are conducted within one kilometer of the community.

Flotation techniques are thought to be appropriate to this course of research and analysis could follow the format presented in Black and McGraw (1985: 219223) and would require systematic soil profile sampling. It should be noted that a flotation technique using a water separation process has proven simpler and superior to those utilizing various chemical separations. The pH of soils and clay content have also be shown regionally to affect flotation processes and such separation strategies should allow for some methods of pre-soaking samples. The collection of microfaunal and floral materials has pragmatically proven to be only as efficient as the processor and controls should be established by such techniques as a 50-count poppy seed addition prior to flotation to test recovery rates per sample (after Wagner 1982). Such a technique was used successfully by Black (1986: 173) with an average recovery rate of $81 \%$ although McGraw in this same application derived ca. 86-92\% rates using \#30-40 stainless steel wire mesh.

Microbotanical recovery may include the collection of environmentally sensitive land snails from soil column samples to postulate changing environmental 
conditions within the local site area. Such data may be compared to other central or south-central sites such as 41WM235 and 41UV60.

Given the presumed periodic nature of site activities and occupations, determinations of seasonality would be most useful in assessing both site function and resource utilization. As examples, wood species identification by Hester (personal communication, notes on file, CAR-UTSA) identified burned acorn at a prehistoric site in nearby Medina County and at least a fall occupation has been postulated at 41BX228 to exploit acorn and other nut harvesting.

The extent and intensity of faunal exploitation such as white-tailed deer should also be considered by the types and extent of recovered bone materials (see TOPICS OF DATA RECOVERY 3:i).

Determinations of spatial patterns may also be expanded through the use of physical and chemical archeometric techniques particularly through the systematic collection of soil phosphate, $\mathrm{pH}$, organic carbon, and other soils chemistry samples. As in other quantifiable tests or collections, a control sample or control process is considered necessary for objective comparisons.

The identification of site features and the recovery of associated material evidence (e.g., specific lithic tool types or feature matrix collections) should identify a number of resource-related, site-specific, characteristics of 41KR243. These include specialized site activity patterns, the range and types of tools used, and possibly, the types of processing involved.

Discrete features such as hearths or burned rock clusters may be more accurately described than in previous works by the use of criteria presented by White (1980) and applying a modification or reduction of Black's (in Black and McGraw 1985: 299) volumetric formula to estimate later Archaic burned rock midden volumes, densities, and total rock weights. Although not applicable in a midden context, the use of such a formula could offer comparative, quantifiable data to burned rock clusters of the Early Archaic occupations at 41KR243. Presented in more detail in Black and McGraw (ibid.), rock density is calculated by dividing total rock weight from a l-meter square by the number of levels, thus giving an average rock weight for a l-meter square, 10-cm level. This figure is multiplied by 10 to obtain an estimate of rock density per cubic meter.

Area estimates were originally based on assumptions of elliptical feature outlines and that these burned rock features were plano-convex in crosssection. A mathematical formula for deriving feature area was summarized as:

$$
\left(\pi \frac{L}{2} \frac{\mathrm{V}}{2}\right)
$$


or pi x 1/2 Length $\times 1 / 2$ Width. Calculations of volume were based on the assumption of a plano-convex feature cross-section and deriving the volume of a spherical cross-section. $\mathrm{H}=$ maximum thickness, $\mathrm{a}=1 / 2$ length, $\mathrm{b}=1 / 2$ width:

$$
1 / 6 \text { pih }\left(h^{2}+3 a b\right)
$$

Volumes could thus be multiplied by estimated density to give total rock weights of the burned rock features.

\section{Population Size and Social Organization}

A poorly understood aspect of Early Archaic occupations is the distribution of populations and the regional application of the band concept of huntergatherer relations. Ethnohistorically, some early 17th and 18th century accounts generally describe regional hunterer-gatherers prior to the introduction of the horse but it would be unsupportable to postulate cultural or population similarities into so early a time frame as the Early Archaic period. It is possible that other ethnographic or ethnological descriptions of modern hunter-gatherers may offer insights into the pattern of site features, division of labor activity areas, and over-all estimates of group sizes based on occupations at 41KR243 but such previous work at other sites has not been addressed by regional researchers to date.

\section{Technology and Typology}

The material remains recovered from 41KR243 may be considered the products or refuse from well established technologies. The vagarities of preservation have limited material remains to those of lithic tools or debris and this unfortunately both characterizes and limits interpretations of regional applications and adaptations of prehistoric technology. Flint knapping to produce a variety of tools and projectile points may be considered a major focus of this aspect of site investigations. The procurement areas, preferences, and types of local and non-local raw materials may all be used as supportive data to supplement a quantitative analysis of both formal and informal tool types and lithic debris. An emphasis of field work should include the recognition of possible discrete single-event work sites and the treatment of such as potential intra-site features.

Formal tool types, including the Martindale projectile point type, should be described and compared to the original type description and recognized regional variants. The diversity of types, postulated tool kits, manufacturing techniques, and use-wear may be compared to similar sites to distinguish similarities and differences. The presence or absence of recognized tool types such as the Clear Fork or Guadalupe distally beveled tools would also aid in defining geographical variations of a Martindale-associated complex. 
4 1KR243

Data Recovery Program
RESEARCH OBJECTIVES

Page 21

\section{Temporal Context}

A definition of the temporal context of $41 \mathrm{KR} 243$ is, given the paucity of reliable Early Archaic radiocarbon assays, a major consideration of research objectives. As noted in the ARCHAEOLOGICAL BACKGROUND, the regional Early Archaic is poorly defined and the cultural phase/period concept, as applied to an understanding of such sites as $41 \mathrm{KR} 243$ was succintly summarized by Johnson (1987: 11)

... And after examining the trait list for the San Geronimo (Prewitt 1981: 77-78), Jarrell (p. 78), and San Marcos (pp.:80-81) phases, can the reader truly sleep well at night secure in the belief that all dart point types of each are, together, the residue of single societies?

To state that the regional Archaic of central Texas is poorly understood is both an understatement and an oversimplification of the problems inherent in data recovery from sites of this time period. As noted in TOPICS OF DATA RECOVERY (item 6: A-H), 41KR243 may contribute a substantial amount of current and significant information from the postulated complex at the Camp Pearl Wheat Site toward a refinement of cultural sequences.

Radiocarbon assays are considered the most critical element in describing the temporal construct. Carbon sampling, collection, and assays should receive particular emphasis and control. As an example, and as appropriate, samples could be split between two non-affiliated or associated testing laboratories as a comparison of dating accuracy.

41KR243, from this perspective, may offer a qualitative refinement of current views and perceptions of this time period not within a regional context, but more appropriately, as Willey and Phillips (1958) suggested, as a site that identifies cultural traits within a local setting (of the upper Guadalupe River drainage). The establishment of a local sequence within this locale and comparisons to other local sequences are thought to be necessary prerequisites for the development of a cultural-geographical, regional, phase.

\section{Spatial Constructs}

The distribution of Early Archaic sites across central Texas and adjacent areas poses an as yet unresolved question of occupational and exploitation patterns. Sites in adjacent areas, such as 41BX274 (McGraw and Hindes 1987) or 41BX228, that contain Martindale projectile points also contain other diagnostic artifacts of the same period. Additionally, such sites also contain distinctive tool types, such as Guadalupe gouges, not found in central Texas locations. A critical review and description of the lithic materials from 41KR243 would thus offer an interesting comparison with the recognized and distinctive areal variations of other Early Archaic lithic assemblages. Tool types and morphological characteristics would also offer insights into inter-regional patterns of resource exploitation and population distributions. 
$41 \mathrm{KR} 243$

RESEARCH OBJECTIVES

Data Recovery Program

Site interpretations should also view the local spatial relationships of $41 \mathrm{KR} 243$ to other nearby sites, a catchment or resource exploitation area, and as possible, integrate 41KR243 into the environmnetal and cultural setting of the upper Guadalupe River drainage.

\section{ANTICIPATED PROBIEM AREAS}

The proposed site investigations of $41 \mathrm{KR} 243$ are considered to be both complex and based on background information from similar, previously identified sites. Not infrequently, the design of such research, profound as it may be, does not address the puzzles of actual field operations. The anticipation of potential problem areas may, in such cases, assure some flexibility to the elements of the data recovery program.

The assumption that $41 \mathrm{KR} 243$ is a single component site is a reasonable interpretation, given the current site data. Since site information is limited, there exists a possibility that 41KR243 actually contains multiple, as yet unrecognized, components. Site investigations should critically view vertical deposits of cultural materials to recognize such conditions during, rather than after, field operations.

$41 \mathrm{KR} 243$ is believed to contain generally undisturbed, intact cultural deposits. The extent of disturbances should be identified and recognized at the beginning of field operations. 
$41 \mathrm{KR} 243$

FIELD METHODOLOGY

Data Recovery Program

Page 23

\section{F I E L D METHODOLOGY}

The new right-of-way contains less than 1000 square meters of undisturbed surface area. Excavation plans call for the hand excavation of 15-20 additional two meter square units. A grid oriented to magnetic north will be superimposed over the site and aligned so Test Unit 1 falls within the grid system. This grid system will encompass all of the proposed right-of-way south of Town Creek and will allow placement of units on both sides of the private drive.

Excavation unit placement will be non-random and partially based on data obtained during the testing phase. As necessary and determined by field interpretations, systematic hand-excavated shovel tests across the site area at predetermined intervals may be employed to sample subsurface deposits and for the collection of column or soils chemistry samples. A block of ca. eight $2 \times 2$ meter squares is proposed around Test Unit 1 (that contained Feature 1, a small fire-fractured limestone hearth). This horizontal block is considered adequate to uncover an associated activity area. A second horizontal block excavation is recommended in the vicinity of Test Unit 2 . Test Unit 2 contained a concentration of lithic debris and the dart point recovered during testing. This locale may represent a discrete lithic workshop area. At least four other $2 \times 2$ meter squares should explore this area and provide a data base for this portion of the site. At least three additional 2-meter square excavation units are proposed, their location dependent upon the distribution of recovered materials from previous block excavations. At least one unit should be placed along the eastern edge of the right-of-way to test for the presence of the site east of the private raodway. Other excavation units will be located as determined by field interpretations and as considered necessary . This would allow for some flexibility of field operations and methods.

Excavation of these units will provide a 15-20\% sample of the site within the project right-of-way and should provide an adequate sample for analysis without producing an unmanageable volume of materials. Recovered materials are believed to represent a sample population that offers validity for interpretations without excessive repetition.

The horizontal extent of the site is approximately $70 \times 40$ meters, however excavations will be confined to the area south of Town Creek and north of Test Unit 3 within the proposed right-of-way. Records will be kept for each level and each unit. Soils will be screened using 0.25 in. or smaller mesh hardware cloth, with materials bagged appropriately.

The data recovery effort is expected to require a period of six weeks. Excavation will be by $1 \times 1$ meter units within a $2 \times 2$ meter grid using arbitrary 10-cm levels. Features will be excavated as cultural units, rather than incorporated into arbitrary units. Living or activity surfaces or contextual associations will be excavated using more refined techniques to provide for greater control. Surfaces will be excavated with small hand tools and 
materials plotted on horizontal and vertical feature maps. Care will be taken to isolate the occupation zones from other fill. Elevations of all levels and individually plotted tools and features will be taken from the site datum. This will maximize potential for identifying activity areas and episodes of occupation.

Feature fill will be water-separated utilizing a flotation process, except for constant volume samples to be taken from each feature, as well as equal volume samples from designated $2 \times 2$ m units. This will maximize the potential for recovery of microflora, fauna, and smaller lithic debitage fragments and provide comparative data for feature and nonfeature areas. The constant volume sample from each feature will be analyzed by specialists for pollen, organic material, soil constituents and artifacts. Processing the constant volume sample from designated $2 \times 2 \mathrm{~m}$ squares will include water-screening one half through 1/16" mesh; the other half, equal in volume to feature samples, will be processed in the same manner as feature fill. In all instances, samples will be collected. Feature 1 in Test Unit 1 will be included in this process.

A scaled topographic map will be made of the site indicating the site grid, features, elevations, and disturbed areas. Piece plotting with tool and other significant artifact elevations will be done to scale on plan maps, each 2 by $2 \mathrm{~m}$ unit; this will allow for a reasonable scale and better control of recording spatial separation of materials. Profiles of at least 2 faces of each 2 meter square will be drawn along with feature profiles. Immediately following the field period there will be a post field conference between the contractor, SHPO, SDHPT, and FHWA. 


\section{SUMMARY}

The data recovery program for $41 \mathrm{KR} 243$ is directed toward a systematic plan of investigation that emphasizes quantitative methodologies for information collection. This will allow not only a more accurate presentation of sitespecific data but will also contribute applicable, quantitative data toward more valid inter-site comparisons. It is believed that an investigation of the cultural-historical setting of aboriginal activities at the Camp Pearl Wheat site will significantly contribute to a clearer understanding of a poorly understood aspect of the Early Archaic period in central Texas. 
The Martindale Projectile Point As A Horizon Marker

In The Regional Early Archaic

A morphological description of the Martindale projectile point type is presented briefly below.

Outline: Triangular blade with edges sometimes striaght, usually convex. Shoulders pronounced to well-barbed, but barbs seldom reach the base. Stem varies from nearly parallel to strongly expanding. The most distinguishing feature of these points is that the base is formed by two distinct convex curves meeting in a depression in the center, a "fish-tail". On other specimens, the base appears to be a simple recurve, but close examination shows the double-convex "fish-tail". It is assumed that this form of base was the result of deliberate effort setting it apart from other bases.

Dimensions: Total length 3.5 to $7 \mathrm{~cm}$, average 4 to $5 \mathrm{~cm}$. Maximum width across shoulders 2.5 to $4.5 \mathrm{~cm}$. Stems 2 to $3.5 \mathrm{~cm}$. wide and $1 / 5$ to nearly $1 / 2$ total length. (data extracted from Suhm and Jelks 1962: 213).

Comments: Primarily found in central Texas. The Martindale point was named by J. Charles Kelley (1947) from examples found in Texas. Local similarities to this point are the Frio and the Uvalde points, both of which have an indented basal edge but only the Uvalde point is of comparable age. In some ways, the point has traits common to some Dalton and Hardin points found elsewhere, the most noticeable being the fishtail stem with smoothed edges. For Hardin points, it would also include the barbed shoulders. (Text extracted from Perino 1985: 242.) The similarity to some Frio points has been noted by others and it is possible an unrecognized Early Archaic point type similar in morphology to the later Frio may some day be defined. Turner and Hester (1985: 120-121) also note that similar types in some cases have been called "Early Barbed" (lower Pecos) or "Early Corner-Notched" (south-central Texas). Bandy is morphologically similar and may be a lower Pecos equivalent. Artifact illustration of the Martindale type extracted from Turner and Hester (1985: 121).

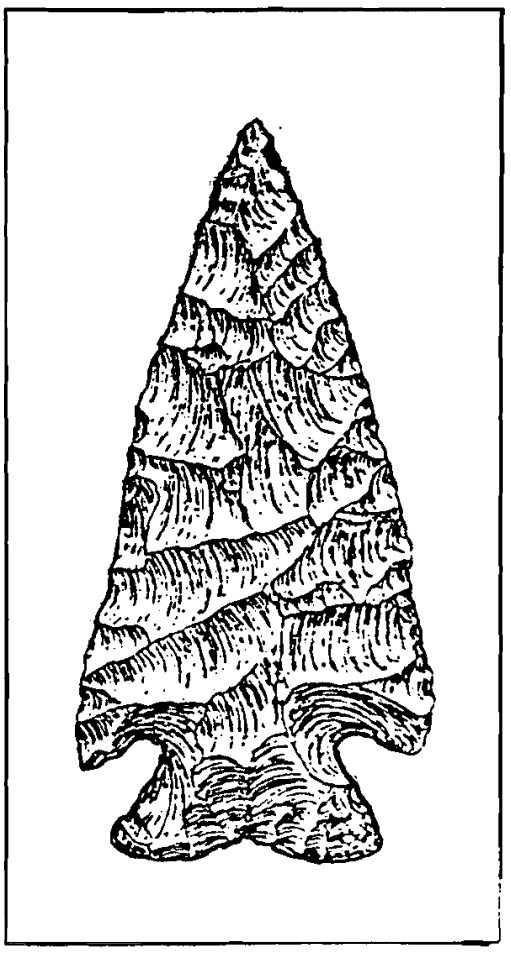




\section{REEERENCES CITED}

Beadles, M.

1971a Interim report Bammel Site (41KR10), analyis of vertical

distribution of projectile points. The Arti-facts, the Journal of the Hill Country Archeological Society 2:2:3-6.

1971b The Bammel Site (41KR10). The Arti-facts, the Journal of the Hill Country Archeological Society 3:1:5-7.

Black, Stephen L.

1986 The Clemente and Hermina Hinojosa Site, 41JW8: A Toyah Horizon Campsite in Southern Texas. Special Report No. 18, Center for Archaeological Research, The University of Texas at San Antonio.

Black, Stephen L. and A. Joachim McGraw

1985 The Panther Springs Creek Site: Cultural Change and Continuity Within the Upper Salado Creek Watershed, South-Central Texas. Archaeological Survey Report No. 100, Center for Archaeological Research, The University of Texas at San Antonio.

Briggs, Alton K.

1971 An Archeological Survey of Ingram Reservoir. Texas Historical Survey Committee and the Texas Water Development Board, Archeological Survey Report 9.

Chisholm, M.

1968 Rural Settlement and Land Use. Hutchinson University Library.

Hester, Thomas R.

1971 Archaeological Investigations at the La Jita Site, Uvalde County, Texas. Bulletin of The Texas ArcheologicalSociety, 42: 51-148.

Jelks, Edward B.

1962 The Kyle Site: A Stratified Central Texas Aspect Site in Hill County, Texas. Department of Anthropology, The University of Texas, Archeology Series, No. 5.

Johnson Jr., LeRoy

1987 A Plague of Phases. Bulletin of the Texas Archeological Society 1987: 1-26.

Kelley, J. Charles

1959 The Desert Cultures and the Balcones Phase: Archaic Manifestations in the Southwest and Texas. American Antiquity 24:3: 276-288.

Luke, Clive J.

1980 Continuing Archaeology on State Highway 16, the Shep Site (41KR109) and the Wounded Eye Site (41KR107. State Department of Highways and Public Transportation Publications in Archaeology Report No. 16. 
McGraw, A. J. and Kay Hindes

1987 Chipped Stone and Adobe; A Cultural Resources Assessment of the Proposed Applewhite Reservoir, Bexar County, Texas. Archaeological Survey Report No. 167. Center for Archaeological Research, The University of Texas at San Antonio.

Perino, Gregory

1985 Selected Preforms, Points, and Knives of the North American Indians. Publ. Privately by Perino, Idabel, Oklahoma.

Prewitt, Elton R.

1981 Cultural Chronology in Central Texas. Bulletin of the Texas Archeological Society 52:65-89.

Sollberger, J.B. and Thomas Roy Hester

1972 The Strohacker Site: A Review of Pre-Archaic Manifestations in Texas. Plains Anthropologist 17(58):326-344.

Suhm, Dee Ann

1960 A Review of Central Texas Archeology. Bulletin of the Texas Archeological Society 29: 63-107.

Suhm, Dee Ann and Edward Jelks

1962 Handbook of Texas Archeology: Type Descriptions. Texas

Archeological Society and Texas memorial Museum, Bull. No. 4., Austin.

Turner, E. S. and T. R. Hester

1985 Field Guide to Stone Artifacts of Texas Indians. Texas Monthly Press, Austin.

Wagner, G. E.

1982 Testing Flotation Recovery Rates. American Antiquity 47(1); 127132.

Willey, G. R. and P. Phillips.

1958 Method and Theory in American Archaeology. The University of Chicago Press.

White, J. R.

1980 A Closer Look at Clusters. American Antiquity 45(1): 66-74.

Weir, Frank A.

1976 The Central Texas Archaic. Unpublished Ph.D. dissertation, Department of Anthropology, Washington State University, Pullman. 